\title{
Practical Approach to the Concept of Lifelong Learning in Linguistic Professional Education (on the Example of Special Field "State and Municipal Governance")
}

\author{
Olga M. Zubkova*a, Elena G. Ivanova ${ }^{\text {b }}$ \\ Elena Y. Nadezhdina ${ }^{a}$ and Elena A. Shaturnaya ${ }^{a}$ \\ ${ }^{a}$ National Research Tomsk State University \\ 36 Lenin, Tomsk, 634050, Russia \\ ${ }^{b}$ Tomsk Region Administration \\ 6 Lenin, Tomsk, 634050, Russia
}

Received 29.07.2015, received in revised form 11.08.2015, accepted 30.09.2015

The article discusses a topical issue of developing a system of ongoing education, which views a foreign language acquisition as an impartial element of enhancement of communicative and intercultural competences level in the context of specialization and professional career, including the sphere of state and municipal governance. The authors of the article present a detailed description of the syllabus for a continuing professional education program "English for Civil Servants in State and Municipal Governance", which is pursued at National Research Tomsk State University on the premises of International Management Department with the support from the European Union project 544283-TEMPUS-1-2013-1-ES-TEMPUS-JPHES "Lifelong Language Learning University Centre Network for New Career Opportunities and Personal Development". The key feature of the program offered to adult students who are already experts in their field is the use of role plays and communicative tasks directly connected with their field of expertise, allowing them to practice using their newly acquired knowledge and skills in a foreign language in situations of their daily working life thus preparing them for professional interaction in a foreign language and making them compatible in the international job market and giving them an opportunity to develop professionally through communication with their colleagues and exchange experience.

Keywords: Life Long learning, a program of additional vocational training, educational communicative situation, role playing games.

The article is written with the financial support of the European Commission within the Tempus IV programme (Project "Lifelong Language Learning University Centre Network for New Career Opportunities and Personal Development (UNICO)”, № 544283-TEMPUS-1-2013-1-ES-TEMPUSJPHES).

DOI: 10.17516/1997-1370-2015-8-11-2398-2407.

Research area: pedagogy.

(C) Siberian Federal University. All rights reserved

* Corresponding author E-mail address: zetaolga@gmail.com 


\section{Introduction}

Globalization processes happening in the today's world put growing demands to specialists in any field and entail the need for continuous professional development and constant acquisition of new knowledge and competencies. The concept of LLL (LifeLong Learning), or "education throughout life", has now become a modern trend of education development in the world and an objective constituent pattern and necessity for a holistic development of a person as a personality and as a professional throughout his life.

In foreign and domestic sources the LLL concept of continuous education is viewed as (Bronevitskiy et.al., 2005; Vishnyakova, 1999):

1. an educational activity throughout life, with the purpose of improving skills/ competencies and/or qualifications for personal, social and/or professional uses;

2. investment in people for the purpose of developing personal, civic and social skills related to their professional activities, and including all forms of education, both formal and informal;

3. a concept of continuous education, which proclaims the person's educational activity as an integral and component part of his way of life at any age;

4. a system of education, which implies continuous improvement of professional knowledge, skills and abilities, taking into account applicable requirements for a professional activity;

5. the essential concept for European society in the field of education and training, as well as a key element in the strategy for creating workplaces, since following the LLL principles helps people to find a decent job and adapt to the environment.

Russia's entering the Bologna process, which aims at unification of national systems of higher education to contribute the formation of a common European market of skilled labor, caused a change in the requirements for training specialists of any profile. At the present stage one of the challenges for higher educational institutions, along with the formation of a harmoniously developed personality possessing a high level of general culture and readiness to think globally, is to train professionals who would be able to adapt freely in their professional field.

Creating a system of universal continuous learning, corresponding to the country's needs and trends of the global labor market, is regarded today as one of the main strategic objectives of the Russian education system. According to most estimates, the economic revival of Russia is impossible without significant improvement of the quality of specialists that provide the country's competitiveness in the world market and the development of all spheres of the state and society.

Knowledge of a foreign language within the Lifelong Learning concept

Knowledge of a foreign language is still an essential attribute of successful selfdetermination and self-realization, but in the context of globalization of modern society a truly competent professional, especially a professional in the field of state and municipal government, should know a foreign language on a fundamentally different level, namely as a tool for professional Intercultural Communication, which will assure his mobility and competitiveness on the international labor market.

Russia's aspiration to enter the European educational medium means that a professional in the field of management need to be aware of everything new happening in his professional environment, in order to be able to engage in crosscultural professional contacts. Acquiring a foreign language in the context of his field and profession 
and mastering it is an essential and integral part of professional culture of any specialist in the field of management. State service is primarily concerned with publicity of professional performance characterized by considerable involvement into various types of communication. We can say that the modern state service is a technology of continuous communication with different people. Traditionally, the function of a specialist in the field of state and municipal government is described as a continuous process of performing the following functions: planning, organization, motivation, control, communications, decision-making (Mineeva, 1999, p. 24). The "communication" function, in turn, incorporates the following qualities:

- the ability to establish interaction;

- the ability to maintain and break contacts;

- the ability to use verbal and nonverbal communication;

- the ability to elicit an adequate response from the interlocutor;

The criteria for evaluation performance of state and municipal employees include such qualities as:

- the ability to convincingly support their point of view;

- the ability to deliver a logical and coherent speech;

- knowledge of methods and techniques of negotiation;

- the ability to effectively conduct negotiations (Mineeva, 1999, p. 24).

All of the above suggests that specialists in the sphere of state and municipal government must possess a qualitatively different level of foreign language. In addition to working with documentation, contracting, preparing business letters, etc., they should be able to participate in interpersonal professional oral communication in a foreign language: organize meetings, negotiations, presentations, establish contacts and maintain international partnership.

Consequently, in the light of the requirements for training specialists in the field of state and municipal government, oral communication in a foreign language becomes a priority. The main goal of a state servant in learning the English language is not just to know rules and professional terms, but to be able to use them in situations of professional interaction, as well as to acquire skills for future mastering the language as a means of crosscultural professional communication, i.e. to constantly raise the level of communication and intercultural competence in the context of his field and professional activities.

\section{Implementation of educational and training programs for state and municipal employees}

AEuropean Union project 544283-TEMPUS1-2013-1-ES-TEMPUS-JPHES «Lifelong Language Learning University Centre Network for New Career Opportunities and Personal Development", implemented by the authors on the basis of the International Management Department of National Research Tomsk State University, has become an attempt to expand the skills and knowledge of a foreign language among professionals in the field of state and municipal government. The project involved development and implementation of a program for additional vocational training "English for state and municipal employees", which takes 120 hours.

The project development included several stages:

- analysis of professional functions and communicative competences requires of a state employee;

- analysis of educational and training programs for future and acting specialists 
in the sphere of state and municipal governance;

- incoming testing aimed at evaluating the level of linguistic competence among state and municipal employees;

- a questionnaire for state and municipal employees aimed at analysis of their motivation factor for learning a foreign language and preferences in the ways of acquiring a language and modes of interaction while studying.

The testing and questioning involved 98 state and municipal employees of different levels of local authorities of Tomsk region. The following are the questions that were used for further analysis:

1. Do you consider knowledge of a foreign language to be a means of stimulating professional growth in the sphere of state and municipal governance? Give your reasons.

2. What aspects of learning a language do your regard as the most beneficial for your professional development?

3. Would you like to discuss problems and situations related to your professional function in the course of language learning? Which are of the most interest/ necessity to you?

4. Which patterns of work and modes of interaction do you feel most comfortable with?

a) Individual work

b) Pair and group work

c) Common discussion

d) Your own answer

5. Which of the following would be the most useful/motivating for you?

a) Reading professional literature/periodic

b) Watching movies/documentaries

c) Role plays

d) Discussions

\section{e) Your own answer}

Analysis of the conducted survey reveled that the majority of respondents $(80 \%)$ view knowledge of a foreign language, namely the English language, as a big advantage in building careers in the sphere of state and municipal governance, as it enables them to become better professionals and opens new perspectives in performing their professional duties. This result showed that state employees have high potential motivation in learning a foreign language for their professional need.

The most demanded aspects of foreign language application were:

- conducting meetings, negotiations and presentations;

- making public speeches;

- contracting, discussing contracts and agreements details;

- professional interactions (resolving conflicts, reaching a consensus, planning cooperation, team building);

- work ethics.

Besides, most of the respondents mentioned professional vocabulary as a necessity for performing their work duties.

As for preferences in terms of patterns of communication and modes of interaction about $75 \%$ of participants chose group work as the most productive and comfortable. The most interesting aspects of language acquisition were discussions of profession-related problems and questions and role plays.

Analysis of language testing showed that most of the participants experience difficulties when choosing appropriate language means to perform the following functions:

- establishing personal contact, choosing situationally appropriate speech patterns;

- understanding and staying within certain styles of communication (formal, informal); 
- expressing their ideas logically and coherently.

Having conducted the above described research, the authors of the project program were able to develop a program for state and municipal employees that contains professionally-oriented foreign-language materials necessary for the formation of foreign language communicative competence in all types of speech activities and aimed at improving the communication skills of state (municipal) employees necessary for successful professional functioning in a foreign language (English).

The program comes in timely due to the urgent need in international and intercultural communication in a foreign language in specific professional, business, and scientific fields to strengthen economic ties through integrating Russian businesses into the world's financial structures and developing friendly contacts between citizens of the Russian Federation and people from other countries.

The program has a modular structure and reflects current trends of a foreign language acquisition within vocational training based on LLL:

- approach to learning as a process of reflecting on life and professional experience;

- emphasizing self-education with the teacher in the role of an organizer of the leaning process;

- modular structure of educational programs;

- wide use of new educational technologies, interactive forms of learning, project methods.

Special attention in the program is paid to the use of active forms and methods of learning, which stimulate students' activity and involve independent and creative task performance. The authors assume that professionally oriented English language training for specialists in the field of state and municipal governance must also be built mainly on task with active participants' involvement, that incorporate communicative objectives in the field of professional performance. In the opinion of the authors the most suitable active forms of organizing educational activities are educational communicative tasks and speech situations and role-playing games, which create conditions for complex influencing the development of linguistic and professional competence and enable to acquire skills which are as close as possible to the natural conditions of interaction in the professional environment. The educational communicative task is viewed, in this instance, as specially formulate conditions, circumstances and a system of relations of interlocutors in order to achieve a certain educational impact on participants of the program in reaching a communicative aim using a foreign language. The following are the examples of educational and speech situations used in the module «Selection of personnel»:

\section{Situation 1}

An employee has decided to leave the company. Prepare a list of questions and ask him / her to clarify his / her position, find out the reason for his / her decision and express your opinion about this situation. While dramatizing, take into account the following information:

\begin{tabular}{|l|l|}
\hline \multicolumn{1}{|c|}{ Clarifying } & \multicolumn{1}{c|}{ Giving an opinion } \\
\hline What exactly ... by ...? & Let me ... the detail of ... \\
Could you ....? & I think we need ... \\
Why ... our company? & Well, I'm ........of .... \\
What aspects of .... deal & I suggest we ... \\
with? & \\
\hline
\end{tabular}

Key words: shift work, to postpone, relationship, staff, contract details, be promoted, salary, job responsibility, to take into account, resignation, to complain about. 
Table 1. List of training sessions

\begin{tabular}{|l|l|}
\hline Topic number & \multicolumn{1}{|c|}{ Training session } \\
\hline 1 & Discussions using educational and speech situations “Specifics of recruitment" (4 hours) \\
\hline 2 & Role-play "Applying for a job" (6 hours) \\
\hline 3 & Paper work "Resume, Cover Letter" (2 hours) \\
\hline 4 & $\begin{array}{l}\text { Contrast usage of Present Simple and Present Continuous. Vocabulary related to the process of } \\
\text { looking for a job, a job interview, characteristics of the modern labor market (2 hours) }\end{array}$ \\
\hline
\end{tabular}

\section{Situation 2}

You are the personnel manager of a company which was created only five years ago and is rapidly expanding. At the moment your company needs an assistant manager. Conduct an interview with an applicant for the post of assistant manager, ask questions about:

- the applicant's personal backgrounds,

- his/her personal traits,

- find out why the applicants apply for the job, what they know about the company and what salary they expect.

The module guides learners through all the stages of getting a job, discusses different types of employment, incorporates speech clichés used in other countries as part of the interview. Special attention is also paid to preparation and writing resumes and cover letters, and a description of work experience. The list of practical training sessions of the module includes (see Table 1):

It is important to mention that the module includes typical, standard situations and most commonly occurring social and professional communicative interaction objectives for the trainees. The authors define a typical communicative situation as "some imaginary scheme or model of a real interaction act, which requires interlocutors to verbally behave within their typical socio-communicative roles" (Skalkin, 2001, p. 173). Most commonly, communication in professional state governance takes place in a formal setting, in the form of individual or group contacts with the purpose of exchanging information of a general and a professional nature in the following situations: participation in international conferences, reception of foreign colleagues (delegations), interviews, meetings, reception of visitors, summoning meetings, business talks, official receptions, negotiations of business partnerships, conversations between a head and an employee, etc.

Careful consideration of typical communicative situations taken from professional and work areas of communication increases motivation for speaking in the classroom, and also makes students participate in verbal classroom interaction by sharing their thoughts and feelings that come from genuinely aspired inner motivation. The verbal stereotype of speech behavior of participants practiced in the classroom in a set of varying replicas of real situations is the basis for mastering professional oral speech discourse in a foreign language. Using typical communicative situations in learning allows the authors of the program to make systematic selection of the most likely communicative acts in various spheres of communication and select appropriate language material that the students must master. Only real circumstances and situations of foreign language professional communication of state and municipal employees are able to ensure that they are driven by their internal motives which 
become natural incentives for speaking and serve as the main condition for the deployment of realistic verbal communication.

This approach ensures observance of one of the rules for implementing the principle of professionally oriented foreign language acquisition within the context of LLL: to stimulate the students' need to solve practical professional problems by involving them in professional activities or their imitation, directly related to their field.

In methodological literature a role-playing game is defined "as spontaneous behavior of students, their reaction to the behavior of other people involved in a hypothetical situation" (Semenova \& Semenova, 2005, p. 16). Role play is a "set of verbal, game and learning activities in which students function in certain roles," (Semenova \& Semenova, 2005, p. 16). Role-plays act as an effective way of involving students in communication, because a game is a simulated replication of real practical activities by the participants. According to Khalimulina
O.V. (Kalimullina, 2003, p. 17), an indispensable element of role-playing games should be the presence of a problem situation that serves as a motive for speaking, making it argumentative and emotional. A role-playing game which involves solving some problem situation allows to activate the communicative activity of the learners to the maximum. Problem solving in general makes a role-playing game a useful tool for developing critical, logical and creative thinking, ability to persuade, justify, support the proposed point of view, giving a sense of realism to communication.

The course of role-playing games can be controlled. It is important here to use communication schemes that clearly indicate characters and overall strategy of their behavior. Communication schemes are designed to stimulate verbal communication behavior of students during the role play, since they do not only set a general extra linguistic task, but also carefully formulate communicative intentions of all the participants.

Table 2. Role cards

Role card 1: Interviewer 1 You are a personnel officer responsible for the recruitment section of a large human
resources department. You are currently looking for somebody for the position of the head of the department
charged with international relations and are meeting with three candidates to discuss the conditions of
employment.
Note that the job requires someone with fluent English (spoken or written) but you are ready to pay for
English courses. You are interested in a person with good social skills, able to represent your local projects in
international affairs of your organization. Use notes below to conduct the interview: educational background;
age; motivation; experience.
Communicative task: Start and conduct the interview. Take into consideration all the facts and details about
applicants, be ready to ask additional questions and then discuss the situation with the second interviewer.
Role card 2: Interviewer 2 You are the senior member of a large HR department. You together with the
personnel officer of your department who is responsible for recruitment are conducting the interview with
three applicants. As far as you know, there is no existing staff with the right level of language and experience
in this department. You want your department to diversify into new areas. You are sure that you need an
employee with new creative ideas how to develop international projects. Exceptionally creative person, well
connected socially, with good English and experience is desirable. Here are some things you'd like to mention
in the interview: managerial competence and skills; flexibility; creativity.
Communicative task: You should be ready to definite conclusion and give your opinion and recommendations
at the end. You do not have to make a decision immediately. If it is necessary, you can fix a date and time for
the next meeting.


Continued Table 2

Role card 3: Interviewee 1 You are applying for the position of the head of the department responsible for international projects. You are currently meeting with the personnel officer and senior member of this department to discuss the conditions of the job. You have been working in administrative department for two years (including the six month probationary period). Although you like your job, lately you have been thinking about looking for a new position. You think it is a challenging post with lots of contracts. You know that they are looking for somebody with fluent English and you worry that your English will not be good enough. But you are aware of the possibility of training courses and you are ready to study. Here are some things to mention at the interview: flexi time (you need to take your child to school); travel allowance; pay rise.

Communicative task: You know both interviewers well: you have been working together in this company for 5 years. This fact is your strong point. Try to be persuasive you're sure you are suitable for this position because you can manage people well.

Role card 4: Interviewee 2 You have just graduated from the international faculty of management (as a second higher education). You also have Master's degree in Business Administration. You are young, very energetic and ambitious person with fluent English. You have now experience but you want to make your career in Civil Service. You also have a strong opinion that women are better managers than men, because they use their intuition to solve problems. Here are some things you would like to mention at the interview: official salary; holidays; opportunity to be promoted.

Communicative task: To tell the truth you feel nervous. It's the first time when you have to take part in interviewing. You must convince the interviewer that only new person can bring innovation and change to the performance of the department.

Here is an example of a role-playing game (see Table 2) offered to participant within the presentation module.

As role-plays are a form of educational models of interpersonal communication and a specific organizational form of learning, they are easily integrated into the classroom. There are several factors that serve as advantages of using role-playing games in preparing specialists for oral professional interaction in a foreign language:

- role-plays imitate specific acts of professional communication;

- role-playing games are based on situations and relationships of participants within their social roles and communicative goals;

- role-playing games have problematic nature, which is one of the most effective, flexible and versatile methods of teaching; they are designed to enhance the learning process and make it more productive, as well as to create and further develop motivation for learning;

- role-playing games teach rules of verbal communication, ensure the knowledge of necessary communicative elements that are appropriate for participation in the game, while the attention of the students is directed to and concentrated on the professional aspect of verbal behavior and speech activity.

\section{Conclusion}

It should be noted that such active forms of teaching and learning as educational communicative situations and role-playing games create conditions for the complex development of linguistic and professional competences and personal growth of students. Besides, the use of situations and games in the learning process promotes the students' communicative initiative, which is manifested in different aspects of their linguistic, professional, communicative, social and moral competences. It also stimulates the 
students' reflection on their learning process and conscious acquisition of subject-subject communication strategy, which is the most effective communication strategy in the area of professional interaction of state and municipal employees. Thus, acquiring a foreign language in the frame of their professional activities as part of the LLL concept through the use of active forms and methods of training will help professionals in the sphere of state and municipal governance to achieve their personal and professional potential in the modern mobile society to the full.

\section{References}

Bronevitskiy, G. A., Bronevitsky, G. G. \& Tomilin, A. N. Psihologo-pedagogicheskiy slovar ofitsera vospitatelya korabelnogo podrazdeleniya [Psychological-Pedagogical Dictionary of the officer of ship division], 2005. $76 \mathrm{p}$.

Kalimullina, O. V. (2003). Rolevyie igryi v obuchenii dialogicheskoy rechi [Role playing in teaching dialogical communication]. Foreign languages at school, 3, 17-20.

Mineeva, T. M. Gosudarstvennaya sluzhba: teoriya i organizatsiya [State Service: Theory and organization].Tomsk, Bibliography, 1999. $160 \mathrm{p}$.

Semenova, T. V. \& Semenova, M. V. (2005). Rolevyie igryi v obuchenii inostrannyim yazyikam [Role playing in learning foreign languages]. Foreign languages at school, 1, 16-18.

Skalkin, V. L. Struktura ustnoyazyichnoy kommunikatsii i voprosyi obucheniya ustnoy rechi na inostrannom yazyike [Structure of oral communication and training issues of foreign language practice]. Moscow, Chrestomathy, 2001. 360 p.

Vishnyakova, S. M. Professionalnoe obrazovanie. Slovar. Klyuchevyie ponyatiya, terminyi, aktualnaya leksika [Professional education. Dictionary. Key concepts, terminology, modern vocabulary]. Moscow, NMC ACT, 1999. 538 p. 


\title{
Практический подход к концепции «Lifelong learning»
}

в рамках языкового профессионального образования

(на примере специальности

«Государственное и муниципальное управление»)

\author{
О.М. Зубкова ${ }^{a}$, Е.Г. Иванова \\ Е.Ю. Надеждина ${ }^{a}$, Е.А. Шатурная ${ }^{a}$ \\ ${ }^{a}$ Наииональный исследовательский \\ Томский государственный университет \\ Россия, 634050, Томск, пр. Ленина, 36 \\ ${ }^{\sigma}$ Администрация Томской области \\ Россия, 634050, Томск, пр. Ленина, 6
}

$\overline{\text { Статья посвящена актуальной теме развития системы непрерывного образования, в рамках }}$ которого знание иностранныхязыков, в частности английского языка, является неотъемлемым атрибутом повышения уровней коммуникативной и межкультурной компетенции в контексте специальности и профессиональной деятельности, в том числе и в области государственного и муниципального управления. Особое внимание авторы статьи уделяют описанию программы дополнительного профессионального образования «Английский язык для государственных и муниципальных служащих», реализуемой на базе международного факультета управления Национально исследовательского томского государственного университета при поддержки проекта Европейского союза 544283-TEMPUS-1-2013-1-ES-TEMPUS-JPHES «Создание сети университетских языковых центров для профессионального и личностного развития человека в рамках парадигмы «образование в течение всей жизни». Представленная программа позволяет слушателям, которые уже являются экспертами в области государственного и муниципального управления, использовать полученные знания и навыки на иностранном языке в ситуащиях повседневного общения.

Ключевые слова: образование в течение всей жизни, программа дополнительного профессионального образования, учебно-речевые ситуаџий, ролевая игра.

Статья написана при финансовой поддержке гранта программы ТЕМПУС IV Европейского Союза (проект «Создание сети университетских языковых иентров для профессионального и личностного развития человека в рамках парадигмы «образование в течение всей жизни», № 544283-TEMPUS-1-2013-1-ES-TEMPUS-JPHES).

Научная спеииальность: 13.00.00 - педагогические науки. 